\title{
Chemical analyses confirm a rare case of seed dispersal by bees*
}

\author{
Cecilia Veronica NunEZ ${ }^{1}$, Marcio Luiz de OLIVEIRA ${ }^{2}$, Renata Duarte LIMA ${ }^{1}$, \\ Ingrit Elida Collantes DiAz ${ }^{3}$, Ézio SARGEnTINI Jr. ${ }^{1}$, Orlando Libório PEREIRA Jr. ${ }^{1}$, \\ Lidia Medina ARAÚJO ${ }^{4}$ \\ ${ }^{1}$ Coordenação de Pesquisas em Produtos Naturais, Instituto Nacional de Pesquisas da Amazônia. Av. André \\ Araújo 2936, Caixa postal 478, Petrópolis, AM, 69011-970, Manaus, Brazil \\ ${ }^{2}$ Coordenação de Pesquisas em Entomologia, Instituto Nacional de Pesquisas da Amazônia. Av. André Araújo \\ 2936, Caixa postal 478, Petrópolis, AM, 69011-970, Manaus, Brazil \\ ${ }^{3}$ Departamento de Química Fundamental, Instituto de Química, Universidade de São Paulo, São Paulo, Brazil \\ ${ }^{4}$ Central Analítica do Departamento de Química, Universidade Federal do Amazonas, Manaus, Brazil
}

Received 3 January 2008 - Revised 16 June 2008 - Accepted 23 June 2008

\begin{abstract}
It has been suggested that dispersal of seeds of Coussapoa asperifolia magnifolia could have endozoochoric dispersal by frugivorous birds and monkeys because the fruits are red when ripe, or exozoochoric dispersal, because the exocarp is mucilaginous and sticky. However, our field observations showed only stingless bees collecting the exocarp with seeds of $C$. asperifolia magnifolia, which are used for building and repairing their nests, from which the plants sprout. This paper aimed to determine the fruit chemical composition, since we postulated that $C$. asperifolia magnifolia is neither consumed by birds nor monkeys due to being very sticky and apparently resinous. Apolar extract analyses revealed the fruits are not resinous but extremely rich in waxes (mainly esterified triglycerides), and polar extract analyses revealed the sugar content to be close to the sensorial minimum level. This probably accounts for why only stingless bees are seen visiting fruits and dispersing seeds.
\end{abstract}

mellitochory / insect-plant interaction / stingless bees / Apidae / Coussapoa

\section{INTRODUCTION}

Despite the enormous diversity, abundance and distribution of insects, they rarely disperse seeds, except for ants of the subfamilies Ponerinae, Myrmicinae, Dolichoderinae and Formicinae, of which 32 genera have been recorded dispersing seeds (Beattie, 1985).

The first record of seed dispersed by bees was for the eucalypt species Corymbia torelliana (F. Muell.) K.D. Hill and L.A.S. Johnson (Myrtaceae) which occurs on the east coast of Australia (Wallace and Trueman, 1995). This

Corresponding author: M.L. de Oliveira, mlolivei@inpa.gov.br

* Manuscript editor: Jacqueline Pierre species has cap-shaped fruits bearing seeds and resin droplets. These seeds are collected by the stingless bee, Trigona carbonaria Smith (Apidae: Meliponinae) and taken to the nest, where the resin is harvested and used for sealing and repairing. Then the seeds are discarded outside the nest. According to those authors, this might be the first record of any animal effectively dispersing eucalypt seeds, which are usually dispersed by wind and gravity, and this phenomenon was termed mellitochory. Subsequently, at least more four stingless bee species have been found dispersing this eucalypt species (Wallace et al., 2008).

The possibility that stingless bees contribute to dispersal of other plant species was suggested by Garcia et al. (1992). The authors 
found that in Manaus, Brazil, and its environs, several stingless bee species bred in man-made beehives carried in their corbiculae seeds collected from Coussapoa asperifolia magnifolia (Trécul) Akkermans and Berg (Urticaceae), a hemi-epiphytic species with strangling roots that occurs mainly in disturbed areas. These seeds and their exocarp are used for nest sealing and repairing but also frequently can be found stuck together in small balls up to $2 \mathrm{~cm}$ in diameter in the bottom of the nest. The function of these balls is unknown. This plant species occurs widely from Panama to the Amazon Basin, including parts of Brazil, Bolivia, Peru, Ecuador, Guyana, Venezuela, and Colombia (Akkermans and Berg, 1982; Berg et al., 1990; Berg, 2000). Its fruits resemble a blackberry with its surface covered with tiny achenes that when ripe are dark red-colored with a sticky and mucilaginous exocarp.

Berg et al. (1990) suggested that C. asperifolia magnifolia could have endozoochoric dispersal by frugivorous birds and monkeys because the fruits are red when ripe, or exozoochoric dispersal, because the exocarp is mucilaginous and sticky. However, during field observations made by one of us (MLO) in Manaus and Rio Branco (in the Brazilian states of Amazonas and Acre, respectively), only stingless bees were seen collecting $C$. asperifolia magnifolia seeds including the exocarp. In this paper we offer evidence that stingless bees may be the only dispersers of $C$. asperifolia magnifolia seeds.

\section{MATERIALS AND METHODS}

\subsection{Field observations}

On the top of a 9-m scaffolding, one of us (MLO) observed the visitors on a single $C$. asperifolia magnifolia plant found in a forest reserve of the Acre Federal University (UFAC) in Rio Branco. The reserve is an urban fragment of 'terra firme' forest. Weekly observations were made over a 6-month period, from 0600 to $1800 \mathrm{~h}$.

Voucher specimens of the bees studied were deposited in the Invertebrate Collection of the $\mathrm{Na}$ tional Institute for Amazon Research (INPA), in
Manaus, and the pressed specimens of C. asperifolia magnifolia went to the UFAC herbarium.

\subsection{Studies of the apolar extracts}

Individuals of $C$. asperifolia magnifolia were collected in November 2002 at the Ducke Reserve near Manaus, Amazonas State. The reserve is an urban fragment of 10000 ha of 'terra firme' forest. Fruits (260 g fresh weight) were dried, ground and extracted with hexane and dichloromethane. The extracts were analyzed through ${ }^{1} \mathrm{H}$ NMR and typical fatty acids signs and triglycerides were observed using spectral analyses. The extracts were hydrolyzed, and the fatty acids were methylated with diazomethane and analyzed by GC/MS (Fig. 1).

\subsection{Studies of the polar extracts}

Nearly $1 \mathrm{~kg}$ (fresh weight) of fruits collected in 2005 also from the Ducke Reserve was lyophilized and ground, yielding $300 \mathrm{~g}$ of plant material which was then extracted with dichloromethane, methanol and water (Fig. 2).

For identifying whether there were any differences in the $C$. asperifolia magnifolia fruit, peel and pulp chemical composition, more fruits $(368 \mathrm{~g}$ fresh weight) were collected in 2005 and these components separated by hand. The peel was detached from the pulp resulting in $16 \mathrm{~g}$ and $47 \mathrm{~g}$ of sample dry weight, respectively. Small globules containing red gelatinous material located between the peel and the pulp were responsible for the fruit's sticky texture when ruptured.

The peels were dried at room temperature and extracted with dichloromethane, methanol and water (Fig. 3). The mashed pulp was extracted with methanol followed by water. Partition of the aqueous extract was performed after the ${ }^{1} \mathrm{H}$ NMR analysis in order to identify the sugar content (Fig. 4).

\subsection{Refractometer solid soluble analysis}

C. asperifolia magnifolia sugars were extracted from the polar extracts and analyzed using a table refractometer in order to determine their potential palatability. Sugar contents can be quantified by a variety of chromatographic methods: optical 


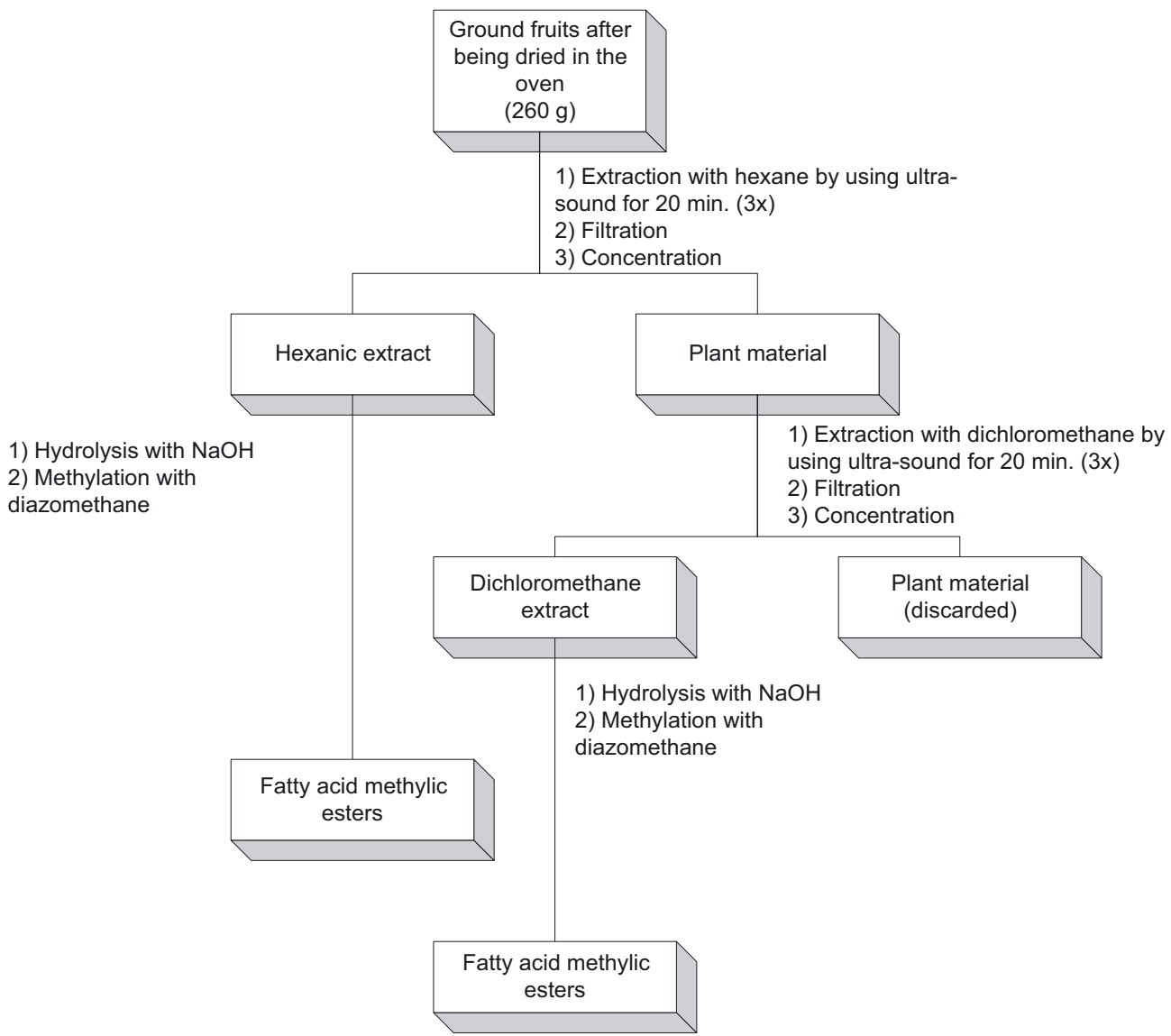

Figure 1. Extraction method for Coussapoa asperifolia magnifolia (Urticaceae) fruit apolar extracts.

(refractrometry, polarimetry and densimetry), Munson Walker, Lane-Eynon or Somogogy-Nelson. The sugars in our sample were analyzed by the optical method using a refractometer which measures the total sugar solution chromatic refraction index, such as soluble solids and expressed in Brix degrees. The equipment was run at $20^{\circ} \mathrm{C}$ using the correction table provided with the apparatus. A few drops from the sample were placed on the measuring prism surface, being traversed by the lighting prism. The clear substances were seen with the transverse light by transparency. The visual field was adjusted to leave a clear-cut division line between the clear and dark zones in the center of the ocular reticulum (Fellers, 1991; Cecchi, 2003).

A small aliquot of each sample was diluted into distilled water to yield a well-concentrated homogeneous solution. Then, the solution was deposited with a dropper on a piece of cotton, and its tem- perature measured for possible reading corrections (Pregnolatto and Pregnolatto, 1985).

These voucher individuals of $C$. asperifolia magnifolia were deposited in the INPA Herbarium in Manaus.

\section{RESULTS AND DISCUSSION}

\subsection{Plant visitors}

We found eight stingless bee species gathering seeds and exocarp of $C$. asperifolia magnifolia, and two other species that collected only exocarp (Tab. I). According to Garcia et al. (1992), only large stingless bees such as the genus Melipona should be capable of collecting C. asperifolia magnifolia exocarpenclosed seeds, because their corbiculae are 


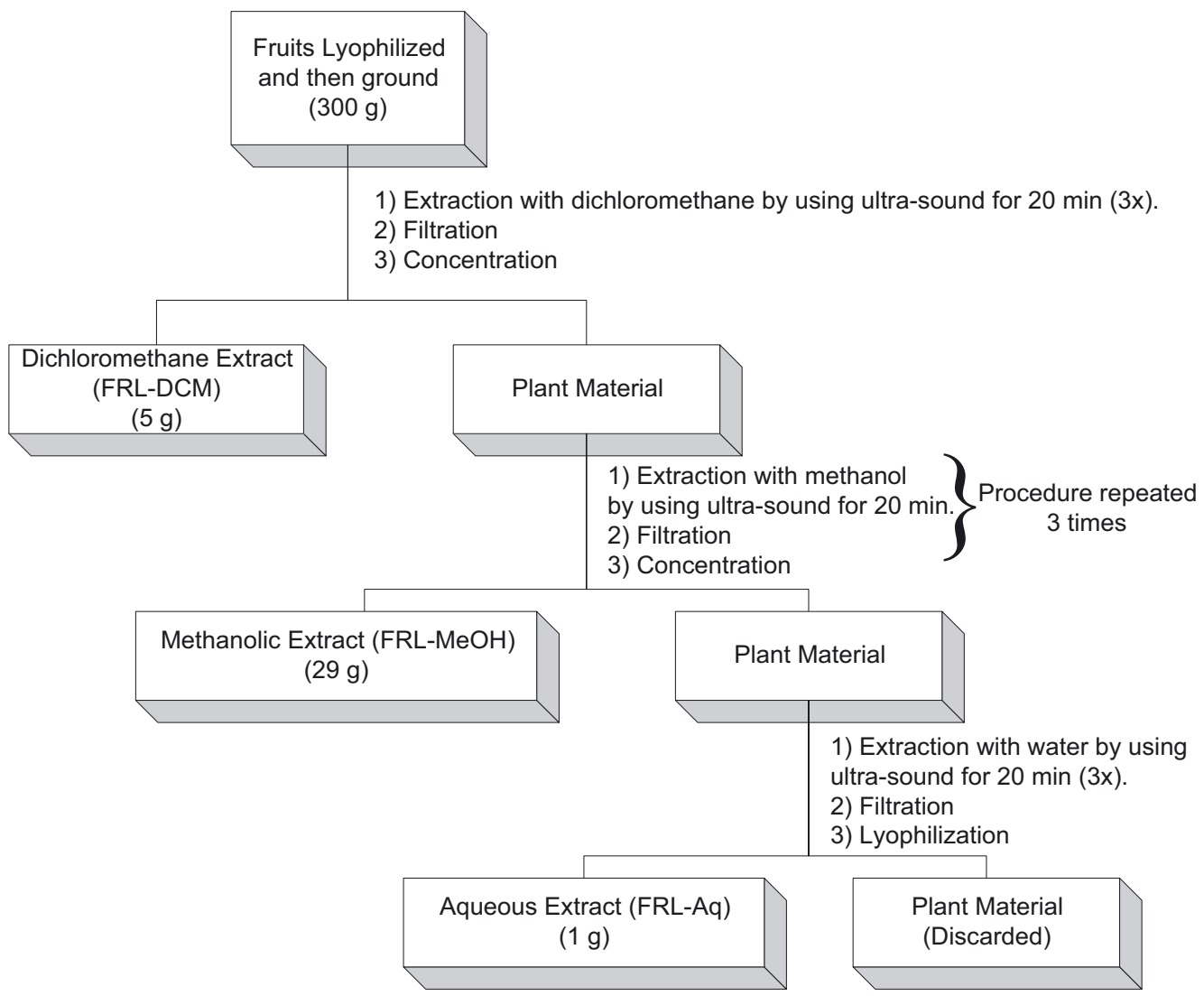

Figure 2. Extraction method for Coussapoa asperifolia magnifolia (Urticaceae) lyophilized whole fruit dichloromethane, methanolic and aqueous extracts.

Table I. Stingless bee species and resources collected in Coussapoa asperifolia magnifolia individuals (Urticaceae).

\begin{tabular}{ll}
\hline Stingless bees species & Resource collected \\
\hline Melipona amazonica Schulz & Seeds and exocarp \\
M. compressipes (Fabricius) & Seeds and exocarp \\
M. brachychaeta Moure & Seeds and exocarp \\
M. eburnea Friese & Seeds and exocarp \\
M. flavolineata Friese & Seeds and exocarp \\
M. fuliginosa Lepeletier & Seeds and exocarp \\
M. nebulosa Camargo & Seeds and exocarp \\
Partamona epiphythophylla Pedro \& Camargo & Seeds and exocarp \\
Trigona fuscipennis Friese & exocarp \\
T. chanchamayoensis Schwarz & exocarp \\
\hline
\end{tabular}




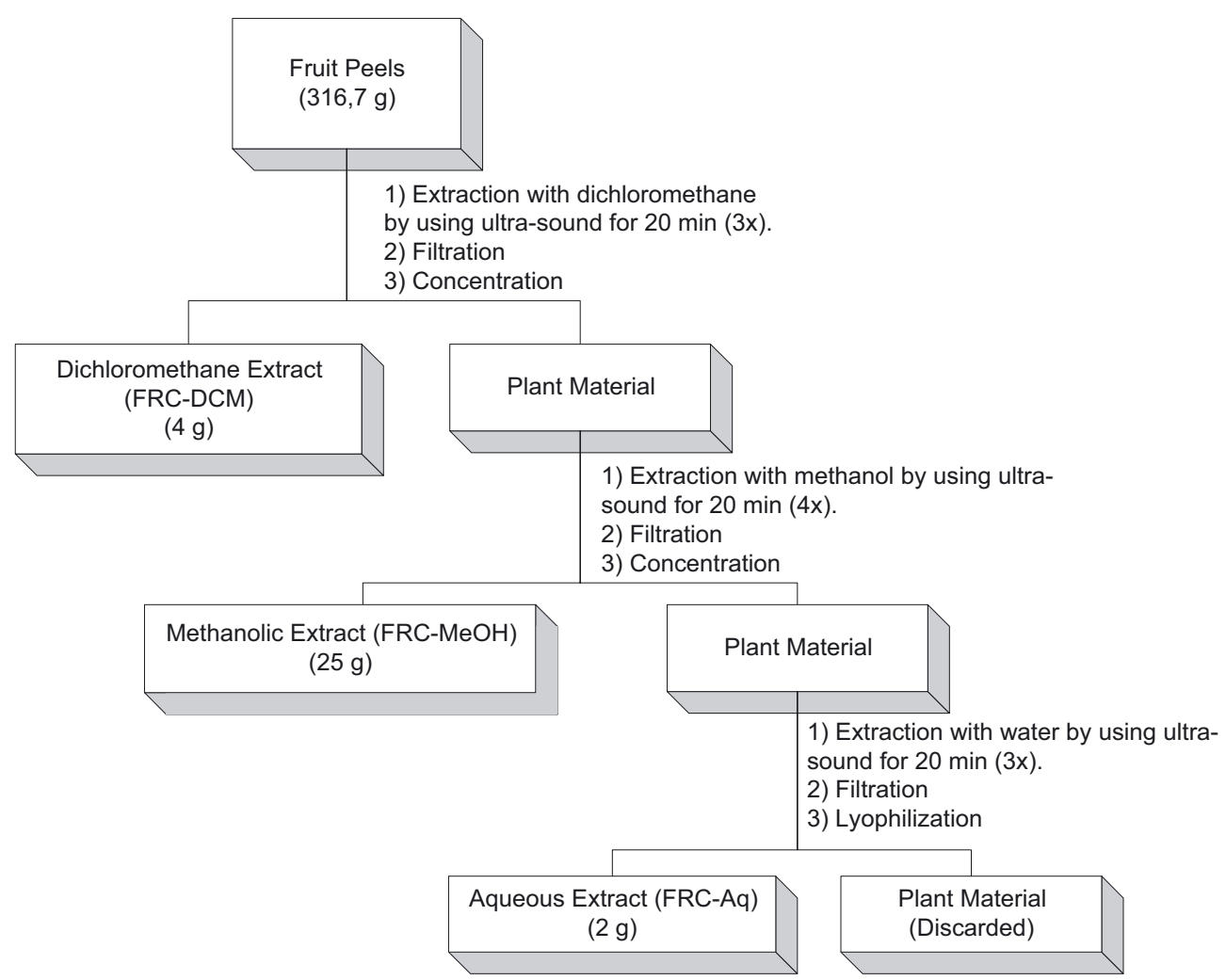

Figure 3. Extraction method for Coussapoa asperifolia magnifolia (Urticaceae) fruit peel extracts.

also big; small stingless bees, with small corbiculae, such as Aparatrigona impunctata (Ducke) and Trigona fuscipennis Friese are capable of collecting only exocarps without seeds. Despite being smaller than Melipona species, Partamona epiphytophylla Pedro and Camargo bees were seen by us collecting both seeds and exocarp. This species has proportionately large and very convex corbiculae, easily capable of carrying $C$. asperifolia magnifolia seeds. On the other hand, Trigona chanchamayoensis Schwarz and T. fuscipennis Friese, which are relatively small bees, were seen collecting only the exocarp.

This seed-gathering behavior may have important consequences for the plant's reproduction. We found several Melipona natural nests and human-maintained beehives, as well as nest walls of Partamona epiphytophylla in Rio Branco and in São Gabriel da Cachoeira (in the state of Amazonas) with C. asperifolia magnifolia seedlings sprouting from fissures (Fig. 5). This may represent a significant mode of successful seed dispersal for this hemi-epiphytic plant.

\subsection{Apolar extract studies}

Through the GC/MS analyses it was possible to identify $91.1 \%$ of the fatty acids present in the apolar extracts (Tab. II), which indicated that these bees use extremely wax-rich fruits, containing mainly triglycerides esterified with palmitic, linoleic, oleic and estearic acids for nest construction. Similar waxes are also produced by abdominal glands of social bees, and are used in pure form or in combinations for nest construction (Nogueira-Neto, 1997). Liquid floral lipids collected by solitary bees from other plant species (especially Malpighiaceae) 


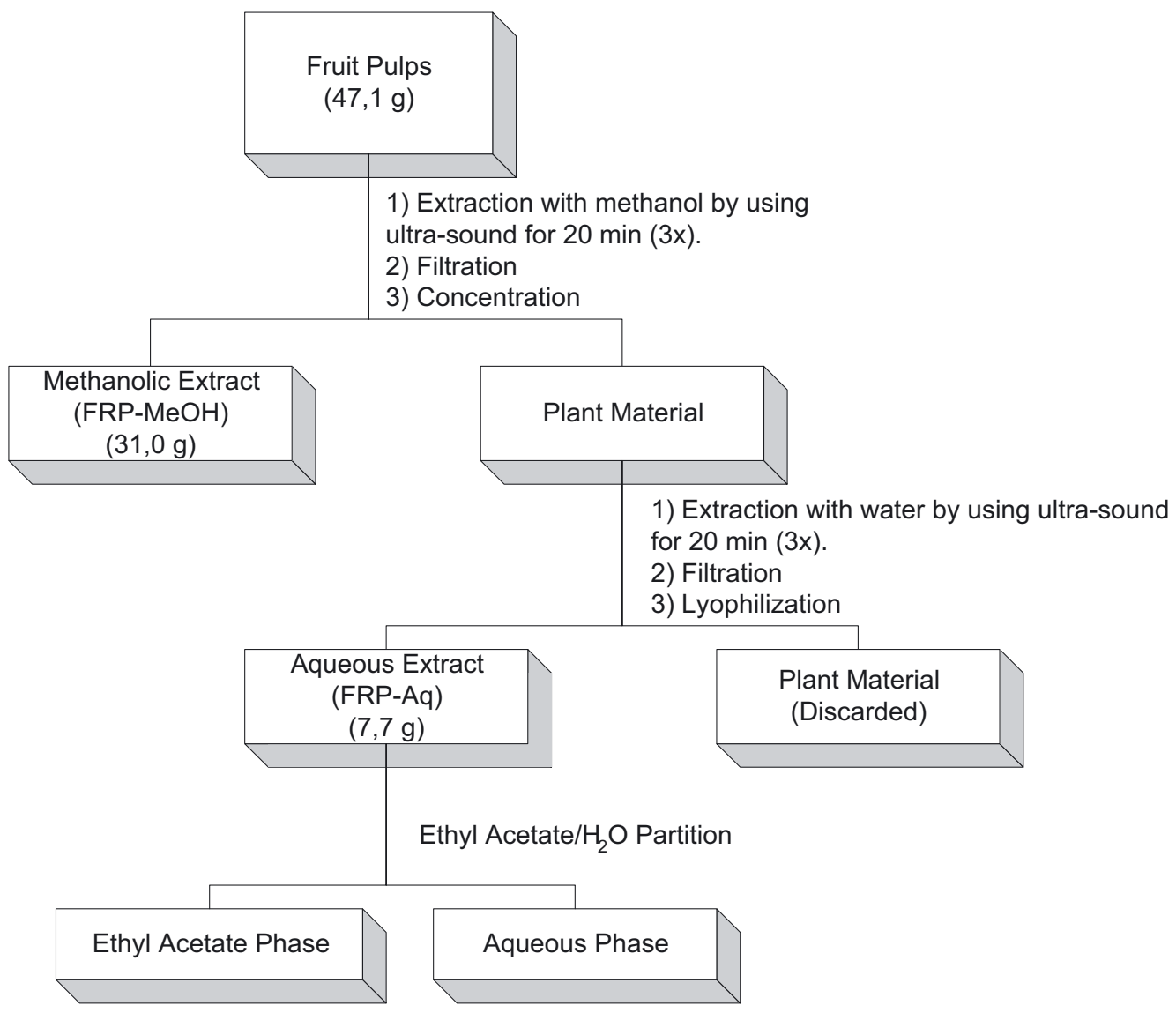

Figure 4. Extraction method for Coussapoa asperifolia magnifolia (Urticaceae) fruit pulp extracts.

Table II. Fatty acids identified in Coussapoa asperifolia magnifolia (Urticaceae) fruit hexanic and dichloromethane extracts.

\begin{tabular}{lccc}
\hline Sample & Temperature $\left({ }^{\circ} \mathrm{C}\right)$ & Read Brix & Corrected Brix \\
\hline FRL-DCM & 30 & 2 & 2.00 \\
FRL-MeOH & 25 & 4 & 4.40 \\
FRL-Aq & 31 & 0 & 0.00 \\
FRC-MeOH & 25 & 6 & 6.40 \\
FRC-Aq & 30 & 3 & 3.00 \\
FRP-MeOH & 28 & 5 & 5.64 \\
FRP-Aq & 25 & 13 & 13.30 \\
\hline
\end{tabular}

FRL-DCM = lyophilized fruits dichloromethane extract, FRL-MeOH = lyophilized fruits methanolic dichloromethane extract, FRL-Aq = lyophilized fruits methanolic aqueous extract, $\mathrm{FRC}-\mathrm{MeOH}=$ fruit peels methanolic extract, FRC-Aq = fruit peels aqueous extract, $\mathrm{FRP}-\mathrm{MeOH}=$ fruit pulps methanolic extract, $\mathrm{FRP}-\mathrm{Aq}=$ fruit pulps aqueous extract. 


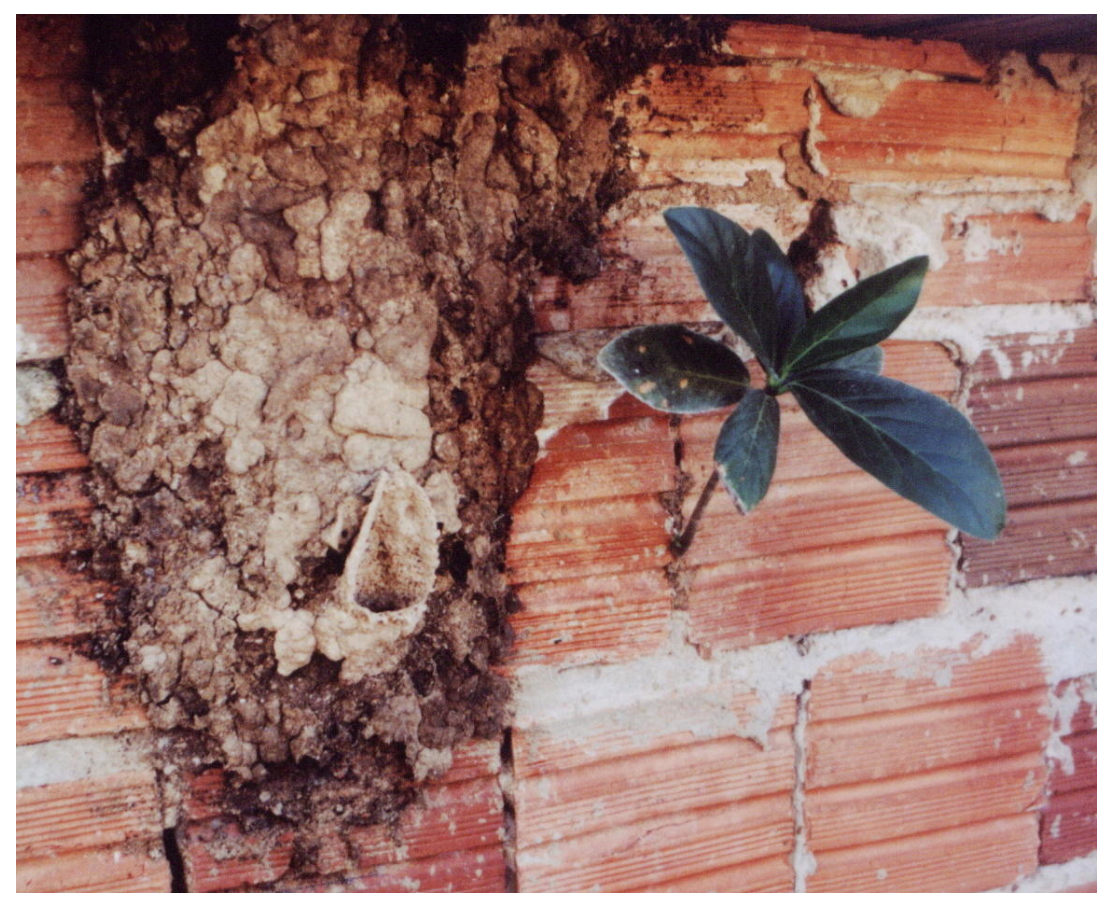

Figure 5. Partamona epiphytophila nest on a house wall with Coussapoa asperifolia magnifolia (Urticaceae) sprouting from its interior.

also contain fatty acids but are only used for brood nutrition (Roubik, 1989).

\subsection{Polar extract studies}

The values obtained (Tab. III) show that only the pulp aqueous extract was palatable $($ read Brix $=13$, and corrected Brix $=13.3)$, though it was close to 10 , the minimum limit. The Brix value must be at least 20 or up to 40 for fruits to be considered sweet or too sweet, respectively (USDA, 2008). This result practically excludes the possibility of consumption by birds and monkeys.

\subsection{Refractometer solid soluble analysis}

The sugars present in low concentration in the fruit extracts were analyzed by ${ }^{1} \mathrm{H}$ and ${ }^{13} \mathrm{C}$ NMR (HSQC and HMBC) to determine their structure. Spectral analysis showed $\alpha$ - and $\beta$-glucose to be present in free form.
The $\beta$-glucose form is expected to be the only one present in the fruit, but it is converted into the $\alpha$ form when extracted with water, due to its lower concentration.

This study showed that fruits of $C$. asperifolia. magnifolia have high levels of triglycerides but very low sugar ( $\alpha$ - and $\beta$-glucose) levels and are sticky, which would likely make them unpalatable to monkeys or birds. However, the triglyceride-rich fruits seem excellent for sealing bee nests in the hot and humid Amazonian climate, since according to Roubik (1989), water may enter in the crevices and damage cells, provisions and brood. These findings corroborate our field observations suggesting that stingless bees are the primary (and perhaps sole) dispersers of C. asperifolia magnifolia seeds.

Hölldobler and Wilson (1990) considered five advantages for plants whose seeds are transported by ants and kept within the colonies, where they can germinate: (1) avoidance of interspecific competition; 
Table III. Brix degree values found for Coussapoa asperifolia magnifolia (Urticaceae) fruit polar extracts.

\begin{tabular}{lcc}
\hline Retention time $(\min )$ & $\%$ & Identified substance \\
\hline 10.715 & 5.0 & Palmitic acid methylic ester (C16:0) \\
12.630 & 76.8 & Linoleic acid methylic ester (C18:2) \\
12.746 & 3.9 & Oleic acid methylic ester (C18:1) \\
12.963 & 3.7 & Estearic acid methylic ester (C18:0) \\
14.084 & 1.0 & Icosanoic acid methylic ester (C20:0) \\
16.184 & 0.7 & Docosanoic acid methylic ester (C22:0) \\
\hline
\end{tabular}

* GC conditions: injector temperature: $250{ }^{\circ} \mathrm{C}$, detector temperature: $310{ }^{\circ} \mathrm{C}$, oven temperature: initial at $120^{\circ} \mathrm{C}$ for $1 \mathrm{~min}$, slope: $10^{\circ} \mathrm{C} / \mathrm{min}$ up to $290^{\circ} \mathrm{C}$, for $10 \mathrm{~min}$.

(2) avoidance of parental competition; (3) avoidance of fire; (4) avoidance of predation and, (5) finding micro-sites with high nutrient levels. In the case of $C$. asperifolia magnifolia, the first four advantages are plausible but, due the plant's hemi-epiphytic habit, this last possibility needs to be confirmed through analyses of soil used by bees in nest construction, as well other nest conditions such as internal temperature and humidity. Since stingless bee nests are found on trunks as well as inside tree cavities, $C$. asperifolia magnifolia seeds germinating in the nests can subsequently spread on host trees, eventually strangling them.

Recently, another case of mellitochory has been reported. In Manaus, worker bees of Melipona seminigra merrillae and M. compressipes manaosensis were observed arriving at meliponaries carrying in their corbiculae seeds with resin of Zygia racemosa (Ducke) Barneby and J.W. Grimes (Bacelar-Lima et al., 2006). Afterwards they were also seen leaving their colonies with the same seeds without the resin and dropping them on the ground nearby, where numerous seedlings could also be observed.

Wallace and Trueman (1995) suggested that mellitochory should be a common phenomenon in the Amazon due to the great richness of stingless bees found there. However in almost twenty years of studies on bees in this region only these two cases have been described to date.

\section{ACKNOWLEDGEMENTS}

We thank Massuo Jorge Kato and Massayoshi Yoshida for the equipment used; Edmilson for col- lecting the fruits; and Ananias Soares da Silva and Gilson da Silva Nunes for laboratory assistance. We also thank Mr. Jorge Antunes for drafting the English version of the original manuscript; William E. Magnusson and Michael Hopkins for their comments, and Carolina Silveira Nunes and Mario Cohn-Haft for language revision.

Des analyses chimiques confirment un cas rare de dispersion des graines par les abeilles.

Mellitochorie / interaction insecte-plante / abeille sans aiguillon / Apidae / Coussapoa / Urticaceae / fruit / composition chimique / triglycéride

Zusammenfassung - Chemische Analysen bestätigen einen seltenen Fall von Samenverbreitung durch Bienen. Die Pflanzen der Gattung Coussapoa besitzen Früchte, die denen von Schwarzbeeren ähneln. Von einigen Autoren wurde vermutet, dass wegen der attraktiven roten Farbe der reifen Früchte deren Verbreitung durch den Verdauungstrakt von Früchte fressenden Vögeln und Affen erfolgt. Sie vermuteten zudem eine externe Verbreitung durch Anheftung an Federn und Fell, da die Früchte schleimig und klebrig sind. Allerdings fanden wir bei unseren Feldbeobachtungen ausschließlich Stachellose Bienen, die Teile von Früchten mit Samen von C. asperifolia magnifolia sammelten, um damit ihr Nest zu bauen bzw. zu reparieren und von wo die Pflanzen dann auskeimten. Wir bestimmten die chemische Zusammensetzung er Früchte von C. asperifolia magnifolia, da wir annahmen, das die Früchte wegen ihrer klebrigen und offensichtlich harzigen Eigenschaften nicht von Affen oder Vögeln gefressen werden. Unserer chemischen Analysen ergab zunächst, dass die Früchte nicht harzig sind. Sie sind extrem reich an Wachsen (vor allem veresterte Trglyceride), dafür ist aber der Zuckergehalte auBerordentlich gering. Diese Analysen legen nahe, dass Früchte von $C$. asperifolia magnifolia ungenießbar für Affen und Vögel sind. Auf der anderen Seite sind die Triglycerid-reichen Früchte hervorragend geeignet, um Bienennester unter den heißen und feuchten Klimabedingungen in Amazonien zu 
verschließen. Dies würde erklären, warum wir ausschließlich Stachellose Bienen beim Besuch dieser Früchte und deren Verbreitung beobachteten. Trotz der großen Diversität an Stachellosen Bienen im Amazonasgebiet scheint die Verbreitung von Früchten durch Bienen (Mellitochory) hier ein eher seltenes Phänomen zu sein.

\section{Mellitochory / Insekt-Pflanze-Wechselwirkung / Stachellose Bienen / Apidae / Coussapoa}

\section{REFERENCES}

Akkermans W.A.P., Berg C.C. (1982) New species and combinations in Coussapoa (Cecropiaceae) and keys to its species, Proc. K. Ned. Akad. Wet., Ser. C, 85, 441-471.

Bacelar-Lima C.G., Freire D.C.B., Coletto-Silva A., Costa K.B., Laray J.P.B., Vilas-Boas H.C., Carvalho-Zilse G.A. (2006) Melitocoria de Zygia racemosa (Ducke) Barneby \& Grimes por Melipona seminigra merrillae Cockerell, 1919 and Melipona compressipes manaosensis Schwarz, 1932 (Hymenoptera, Meliponina) en la Amazonía Central, Brasil, Acta Amaz. 36, 343-348.

Beattie A.J. (1985) The evolutionary ecology of antplant mutualisms, Cambridge University Press, New York.

Berg C.C. (2000) Cecropiaceae, in: Riina R. (Ed.), Flora de Venezuela, Fundación Instituto Botánico de Venezuela "Dr. Tobias Lasser", Caracas, pp. 224-228.

Berg C.C., Akkermans W.A.P., van Heusden C.H. (1990) Cecropiaceae: Coussapoa and Pouroma, with an introduction to the family. Flora Neotropica, Monographs 51, The New York Botanical Garden, New York.
Cecchi H.M. (2003) Fundamentos teóricos e práticos em análise de alimentos, Ed. Campinas, 2nd ed. rev., Campinas, SP, pp. 74-76.

Fellers P.J. (1991) The relationship between the ratio of degrees Brix to percent acid and sensory flavor in grapefruit juice, Food Technol. 45, 68-75.

Garcia M.V.B., Oliveira M.L., Campos L.A.O. (1992) Use of seeds of Coussapoa asperifolia magnifolia (Cecropiaceae) by stingless bees in Central Amazonian forest (Hymenoptera: Apidae: Meliponinae), Entomol. Gen. 17, 255-258.

Hölldobler B., Wilson E.O. (1990) The Ants, SpringerVerlag, Berlin.

Nogueira-Neto P. (1997) Vida e criação de abelhas indígenas sem ferrão, Editora Nogueirapis, São Paulo.

Pregnolatto W., Pregnolatto N.P. (1985) Normas Analíticas do Instituto Adolfo Lutz, Métodos Químicos e Físicos para Análise de Alimentos, Vol. 1, 3rd ed., Governo do Estado de São Paulo, Instituto Adolfo Lutz, São Paulo, SP.

Roubik D.W. (1989) Ecology and natural history of tropical bees, Cambridge Tropical Biology series, Cambridge.

USDA (2008) http://www.ams.usda.gov/standards/ (accessed on 12 August 2008).

Wallace H.M., Trueman S.J. (1995) Dispersal of Eucalyptus torelliana seeds by the resin-collecting stingless bee Trigona carbonaria, Oecologia 104, 12-16.

Wallace H.M., Howell M.G., Lee D.J. (2008) Standard yet unusual mechanisms of long-distance dispersal: seed dispersal of Corymbia torelliana by bees, Diversity and Distributions 14, 87-94. 